\title{
LOU/C, Rat Strain
}

National Cancer Institute

\section{Source}

National Cancer Institute. LOU/C, Rat Strain. NCI Thesaurus. Code C14383.

Develop spontaneous plasmacytomas after about 8 months of age, with an incidence of about 30\% in males and 16\% in females. These develop rapidly, and may be detected by palpation. They usually develop in the ileocoecal lymph nodes, and about $60 \%$ of them synthesis monoclonal immunog lobulins (Bence-Jones proteins) of IgG1 (35\%), IgE (36\%) or IgA classes. 